\title{
The first record of the copepod genus Clausidium Kossmann, 1875 (Crustacea: Copepoda: Poecilostomatoida: Clausiididae) parasitic on burrowing callianassid shrimps from the Black Sea
}

\author{
Первая находка копепод рода Clausidium Kossmann, 1875 \\ (Crustacea: Copepoda: Poecilostomatoida: Clausiididae), \\ паразитирующих на роющих креветках-камлианассидах \\ в Черном море
}

\author{
Ivan N. Marin ${ }^{1}$, Ilya S. Turbanov ${ }^{2}$ \\ И.Н. Марин ${ }^{1}$, И.С. Турбанов
}

\footnotetext{
${ }^{1}$ A.N. Severtzov Institute of Ecology and Evolution of RAS, Leninsky pr. 33, Moscow, 117071, Russia.

E-mail: coralliodecapoda@mail.ru,vanomarin@yahoo.com

${ }^{2}$ Radiology Research and Practical Centre, Moscow, Russia.

${ }^{2}$ I.D. Papanin Institute of Biology of Inland Waters of RAS, Borok, Nekouzsky region, Yaroslavl Province, 152742, Russia. E-mail: turba13@mail.ru

${ }^{2}$ Научно-практический центр медицинской радиологии («ГБУЗ НПЦМР ДЗМ»), Москва, Россия.

${ }^{1}$ Институт проблем экологии и эволюции им. А.Н. Северцова РАН, Ленинский просп., 33, Москва, 117071, Россия.

${ }^{2}$ Институт биологии внутренних вод им. И.Д. Папанина, п. Борок, Некоузский р-н, Ярославская область, 152742, Россия.
}

KEY WORDS: Crustacea, Copepoda, Clausidium, Callianassidae, Pestarella, parasitic, new records, Black Sea. КЛЮЧЕВЫЕ СЛОВА: Crustacea, Copepoda, Clausidium, Callianassidae, Pestarella, паразитические, новые находки, Черное море.

ABSTRACT. The species of Clausidium Kossmann, 1875 (Crustacea: Copepoda: Poecilostomatoida: Clausidiidae) identhified as Clausidium apodiformis (Philippi, 1839) is recorded for the first time parasitic on shallow water burrowing callianassid shrimp Pestarella candida (Olivi, 1792) (Decapoda: Axiidea: Callianassidae) from Kazachiya Inlet (Sevastopol') of Crimean Peninsula, representing the first record of the species and the genus from the Black Sea. Remarks on the ecology of this copepod species in the Black Sea are presented.

РЕЗЮМЕ. Представители рода Clausidium Kossmann, 1875 (Crustacea: Copepoda: Poecilo-stomatoida: Clausidiidae), определенные как Clausidium apodiformis (Philippi, 1839), впервые отмечены паразитирующими на мелководных роющих креветках-каллианассидах Pestarella candida (Olivi, 1792) (Decapoda: Axiidea: Callianassidae) в бухте Казачья (Севастополь) Крымского полуострова, представляя первую находку рода и вида в водах Черного моря. Данные по экологии этих копепод представлены в работе.

\section{Introduction}

Representatives of the genus Clausidium Kossmann, 1875 (Crustacea: Copepoda: Poecilostomatoida: Clausiididae) usually found parasitic inside holes or as external parasites of burrowing callianassid shrimps (Crus- tacea: Decapoda: Callianassidae) [Light, Hartman, 1937; Humes, 1949, 1957; Corsetti, Strasser, 2003; Kihara, Rocha, 2013]. Presently, 11 species of the genus are known worldwide [Light, Hartman, 1937; Vervoort, Ramirez, 1966; Kihara, Rocha 2013; Walter, Boxshall, 2015]. One species, Clausidium apodiformis (Philippi, 1839) (= C. testudo Kossmann, 1867), is known from the Mediterranean (including Adriatic Sea) parasitic on callianassid shrimps Calianassa subterranea (Montagu, 1808) and Pestarella candida (Olivi, 1792) (Decapoda: Axiidea: Callianassidae) [Philippi, 1839; Kossmann, 1874; Manning, Stevcic, 1982]. Until now, Clausidium was not reported for the Black Sea where the latter host shrimp species was recently collected and re-described during in the course of a special survey [Marin, 2013a; present paper] as well as several new burrowing species for Russian fauna [Marin, 2010, 2013b; Marin et al., 2011, 2013].

Nevertheless, during studying of ecological features of the population of $P$. candida in Kazachiya Bay, Sevastopol, Crimean Peninsula, the Black Sea $\left(44^{\circ} 34^{\prime} 6^{\prime \prime} \mathrm{N} 33^{\circ} 24^{\prime} 44^{\prime \prime} \mathrm{E}\right)$ in August 2015 we found numerous parasitic copepods living on the body of collected shrimps. Careful identification showed that these copepods clearly referred to the genus Clausidi$u m$ having sucking discs on endopods of legs 1 to 4 and were identified as Clausidium apodiforme (Philippi, 1839) representing the first record of the species and the genus in the Black Sea. 


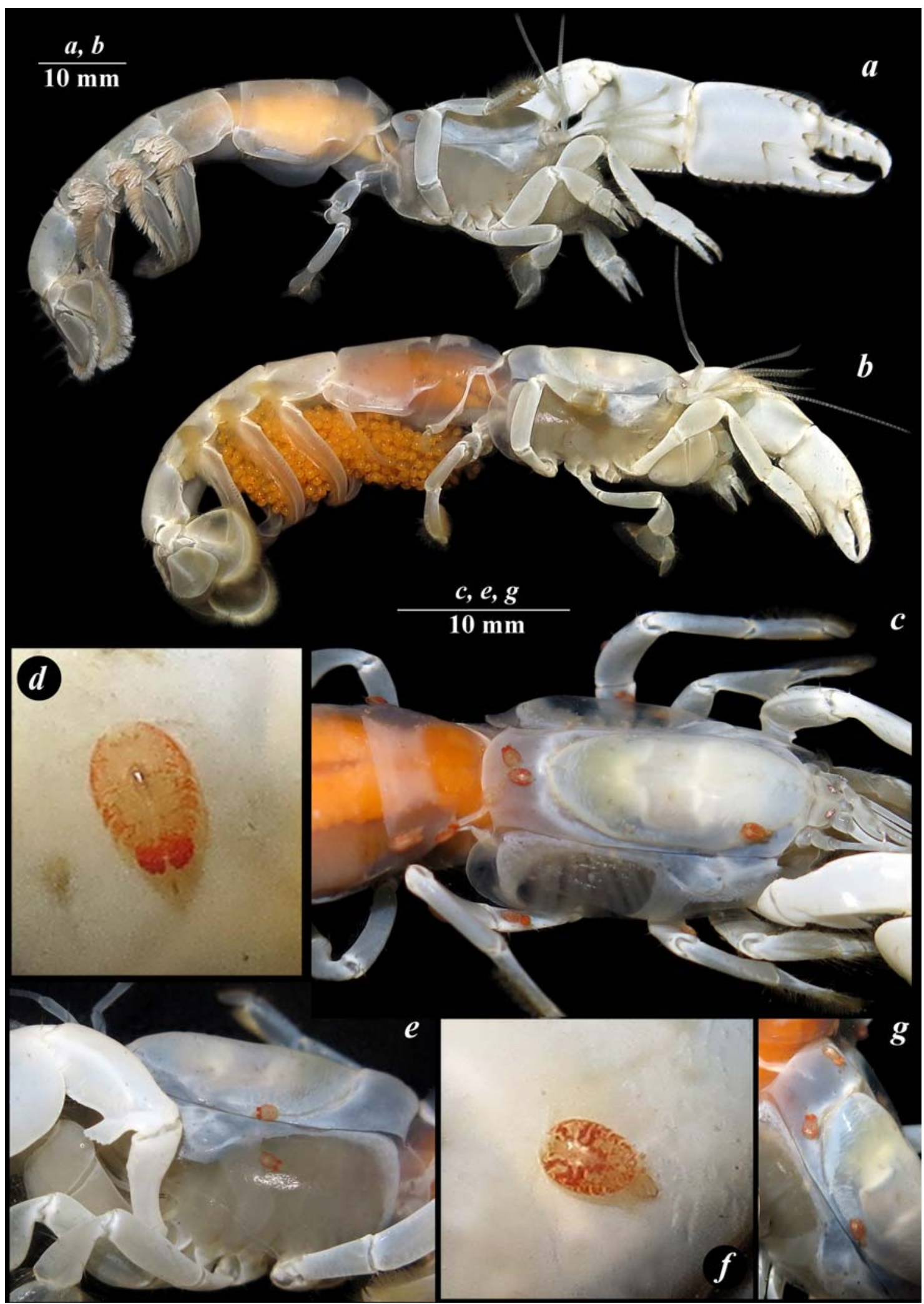

Fig. 1. General view of host callianassid shrimp Pestarella candida (Olivi, 1792) from Kazachiya Bay, Sevastopol, Black Sea ( $a$ male, $b$ - ovigerous female); $d, f$ - general view of Clausidium apodiformis (Philippi, 1839); $c, e, g-$ specimens of Clausidium on the body of host shrimp.

Рис. 1. Общий вид креветки-хозяина Pestarella candida (Olivi, 1792), бухта Казачья, Севастополь, Черное море $(a-$ самец, $b-$ половозрелая самка); $d, f$ - общий вид Clausidium apodiformis (Philippi, 1839); $c, e, g$ - особи Clausidium на теле креветкихозяина. 


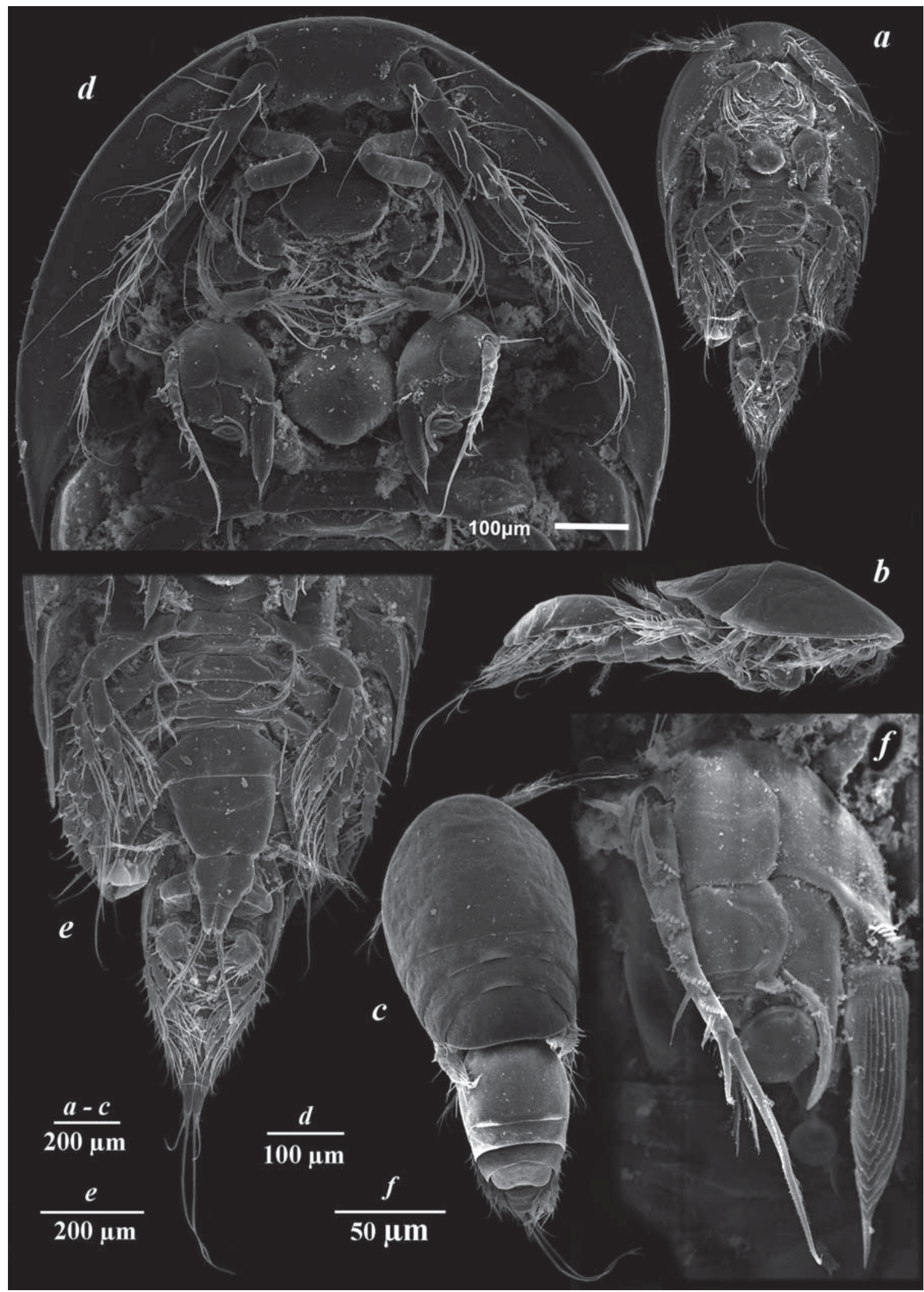

Fig. 2. Clausidium apodiformis (Philippi, 1839), Kazachiya Bay, Sevastopol, Black Sea: $a$ - general view, ventral; $b$ - lateral view; $c$ - dorsal view; $d$ - distal segments, ventral view; $e$ - proximal segments, ventral view; $f$ - P1, anterior.

Рис. 2. Clausidium apodiformis (Philippi, 1839), бухта Казачья, Севастополь, Черное море: $a-$ общий вид снизу; $b-$ вид сбоку; $c$ - общий вид сверху; $d$ - дистальные сегменты тела, вид снизу; $e$ - проксимальные сегменты тела, вид снизу; $f$ - P1, вид снизу. 
All collected material is deposited in the collection of the Laboratory of Ecology and Morphology of Marine Invertebrates of the A.N. Severtsov Institute of Ecology and Evolution of RAS (LEMMI, Moscow). Species names and modern taxonomic position are given according to the international database WoRMS (World Register of Marine Species) and Marine Species Identification Portal. The number of observed specimens (n) is indicated for each host shrimp species. Only primary synonyms are given.

\section{Taxonomy}

Subclass Copepoda Milne-Edwards, 1840

Order Poecilostomatoida Burmeister, 1835

Family Clausidiidae Embleton, 1901

Genus Clausidium Kossmann, 1875

\section{Clausidium apodiformis (Philippi, 1839)} Figs 1, 2 .

Hersilia apodiformis Philippi, 1839: 128, pl. 4, figs. 9-11. Clausidium testudo Kossmann, 1867: 11, pl. 6 [type locality: Mediterranean].

Clausidium apodiformis. - Kossmann, 1874: 11

MATERIAL EXAMINED. 18 ovigerous females; 25 males (LEMMI) - North Atlantic Ocean, Black Sea, Crimean Peninsu-

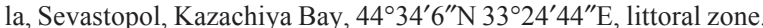
clean sand bottom with some seaweeds, on body of burrowing shrimps Pestarella candida collected with the help of yabbi-pump, coll. I. Marin, I. Turbanov, G. Turbanov, 6-8.08.2015.

ECOLOGICAL REMARKS. All specimens of copepods were collected from the body of callianassid shrimps Pestarella candida (Olivi, 1792) (Decapoda: Axiidea: Callianassidae) $(\mathrm{n}=15)$ (Fig. 1), while no parasitic copepods were found on the other burrowing shrimp species Upogebia pusilla (Petagna, 1792) (Decapoda: Gebiidea: Upogebiidae) $(n=20)$ common in the same habitats and the area and numerously collected during the same sampling. This indicates that representatives of the genus Clausidium are more specific to callianassid shrimps while their records onburrowing shrimps of the family Upogebiidae [i.e. Campos et al., 2009] are possibly occasional. Several other morphologically similar parasitic poecilostomatoid copepods can be found on crustaceans such as representatives of the genus Hemicyclops Boeck, 1872 (Clausidiidae) and Anthessius Della Valle, 1880 (Anthessiidae) [Light, Hartman, 1937; Vervoort, Ramirez, 1966; Conradi et al., 2012].

DISTRIBUTION. Clausidium apodiformis (Philippi, 1839) (Fig. 2) has been previously recorded from the Mediterranean basin as a parasite of callianassid $P$. candida and Callianassa subterranea (Montagu, 1808) (Decapoda: Axiidea: Callianassidae) [Philippi, 1839; Kossmann, 1874; Manning, Stevcic, 1982] and its record in the Black Sea is expected.

ACKNOWLEDGEMENTS. This work was supported by RFBR grant 15-04-05125 a "Symbiotic communities associated with large marine crustaceans: diversity, structure, biological relationships" and 15-34-20863 mol a ved. SEM photographs were taken on Microscope JSM-6 $\overline{5} 1 \overline{0} \mathrm{LV}$ JEOL in the Centre of Microscopy of I.D. Papanin Institute of Biology of Inland Waters of RAS. The authors are grateful to Georgyi Turbanov for the help during shrimp sampling.

\section{References}

Campos E., Campos A.R., Manriquez I. 2009. Intertidal Thalassinidean Shrimps (Thalassinidea: Callianassidae and Upogebidae) of the West Coast of Baja California, Mexico: Annotated Checklist, Keys for Identification and Symbionts // Crustaceana. Vol.82. No.10. P.1249-1263.

Conradi M., Marin I., Martin D. 2012. An unexpected parasitic relationship between a new species of Anthessius (Copepoda: Cyclopoida) and a decapod crustacean, Alpheus macrocheles (Hailstone, 1835) from the NW Mediterranean Sea // Journal of Crustacean Biology. Vol.32. No.5. P.860-870.

Corsetti J.L., Strasser K.M. 2003. Host selection of the symbiotic copepod Clausidium dissimile in two sympatric populations of ghost shrimp // Marine Ecology Progress Series. Vol.256. P.151-159

Humes A.G. 1949. A new copepod (Cyclopoida: Clausidiidae) parasitic on mud shrimps in Louisiana // Transactions of the American Microscopical Society. Vol.68. P.93-103.

Humes A.G. 1957. Une nouvelle espèce de Clausidium (Copepoda, Cyclopoida) parasite d'une Callianassa au Sénéga // Bulletin de l'Institut français d'Afrique noire (A). Vol.19. P.485-490.

Kihara C.T., Rocha C.E.F. 2013. First record of Clausidium (Copepoda, Clausidiidae) from Brazil: a new species associated with ghost shrimps Neocallichirus grandimana (Gibbes, 1850) (Decapoda, Callianassidae) // ZooKeys. Vol.335. P.47-67.

Kossmann R. 1874. Ueber Clausidium testudo, einen neuen Copepoden, nebst Bemerkungenüber das System der halbparasitischen Copepoden // Verhandlungen der Physikalischen Gesellschaftzu Würzburg. Bd.7. S.280-294.

Light S.F., Hartman O. 1937. A review of the genera Clausidium Kossmann and Hemicyclops Boeck (Copepoda, Cyclopoida), with the description of a new species from the northeast Pacific // University of California publications in zoology. Vol.41. P.173-188

Manning R.B., Stevcic Z. 1982. Decapod fauna of the Piran Gulf // Quaderni del Laboratorio di Tecnologiadella Pesca. Vol.3. No.2-5. P.285-304.

Marin I. 2010. Re-description of rare alpheid shrimp Betaeus levifrons Vinogradov, 1950 (Crustacea, Decapoda, Alpheidae) from the Peter the Great Bay, the Russian coast of the Sea of Japan // Zootaxa. Vol.2613. P.51-60.

Marin I.N. 2013a. Atlas of Decapod Crustaceans of Russia. Moscow: KMK Scientific Press. 2013. 145 p.

Marin I. 2013b. A new species of callianassid ghost shrimp of the genus Nihonotrypaea Manning \& Tamaki, 1998 (Crustacea, Decapoda, Axiidea, Callianasidae) from southern Posiet Bay of the Russian coast of the Sea of Japan // Zootaxa. Vol.3694. No.5. P.434-444.

Marin I.N., Korn O.M., Kornienko E.S. 2011. Symbiotic crab Sestrostoma balssi (Shen, 1932) (Varunidae: Gaeticinae) from Vostok Bay, Sea of Japan: a new species for the fauna of Russia // Russian Journal of Marine Biology. Vol.37. No.6. P.509-510.

Marin I.N., Korn O.M., Kornienko E.S. 2013. [Upogebia yokoyai Makarov, 1938 (Decapoda: Gebiidea: Upogebiidae) - a new species of burrowing shrimps for the Sea of Japan] // Russian Journal of Marine Biology. Vol.39. No.3. P.221-226 [in Russian].

Philippi A. 1839. Einige zoologische Noise // Archiv für Naturgeschichte. Bd.5. S.113-134.

Walter T.C., Boxshall G. 2015. World of Copepods database. Accessed at http://www.marinespecies.org/copepoda on 2015-08-27

Vervoort W., Ramirez F. 1966. Hemicyclops thalassius nov. spec. (Copepoda, Cyclopoida) from Mar del Plata, with revisionary notes on the family Clausidiidae // Zoologische Mededelingen. Vol.41. P.195-220

Responsible editor V.A. Spiridonov 